\title{
Older workers in the construction industry: results of a routine health examination and a five year follow up
}

\author{
Volker Arndt, Dietrich Rothenbacher, Hermann Brenner, Eckart Fraisse, \\ Bernd Zschenderlein, Ulrich Daniel, Stephan Schuberth, Theodor M Fliedner
}

\begin{abstract}
Objective-To describe the health status of older construction workers and the occurrence of early retirement due to disability or of mortality within a five year follow up.
\end{abstract}

Methods-Firstly, a cross sectional study was performed among 4958 employees in the German construction industry, aged 40-64 years, who underwent standardised routine occupational health examinations in 1986-8. The study population included plumbers, carpenters, painters/varnishers, plasterers, unskilled workers, and white collar workers (control group). Job specific prevalence and age adjusted relative prevalence were calculated for hearing loss, abnormal findings at lung auscultation, reduced forced expiratory volume, increased diastolic blood pressure, abnormalities in the electrocardiogram, increased body mass index, hypercholesterolaemia, increased liver enzymes, abnormal findings in an examination of the musculoskeletal system, and abnormalities of the skin. Secondly, follow up for disability and all cause mortality was ascertained between 1992 and 1994 (mean follow up period $=4.5 \mathrm{y}$ ). Job specific crude rates were calculated for the occurrence of early retirement due to disability and for all cause mortality. With Cox's proportional hazards model, job specific relative risks, adjusted for age, nationality, and smoking were obtained. Results-Compared with the white collar workers, a higher prevalence of hearing deficiencies, signs of obstructive lung diseases, increased body mass index, and musculoskeletal abnormalities were found among the construction workers at the baseline exam. During the follow up period, 141 men died and 341 men left the labour market due to disability. Compared with white collar workers, the construction workers showed a $3 \cdot 5$ to 8.4fold increased rate of disability $(P<0.05$ for all occupational groups) and a 1.2 to 2.1-fold increased all cause mortality (NS).

Conclusions-This study shows the need and possibilities for further health promotion in workers employed in the construction industry, targeting both work related conditions and personal lifestyle factors. Rehabilitation measures should be enforced to limit the rate of disability among construction workers.
(Occup Environ Med 1996;53:686-691)

Keywords: construction workers; early retirement; disability; mortality

The working conditions in the construction industry have been improved during the past decades and efforts have been made to reduce the amount of heavy lifting and carrying, but hard physical labour, static work, climatic influences, noise, and dust are still considerable burdens for construction workers.

Official statistics of occupational diseases published by the German Workmen's Compensation Board show that deafness caused by exposure to noise, occupational dermatoses, pneumoconioses, and disorders of the musculoskeletal system are the most frequent occupational diseases in the German construction industry. ${ }^{1}$ Although young workers may compensate for these strains or may choose another occupation, older workers have more limited capacities and cannot easily transfer to another field of work. Among construction workers $63 \%$ of all retirements are due to medical conditions. In contrast, among the general workforce in Germany this proportion is about $44 \% .^{2}$ Disorders of the musculoskeletal system are the predominant cause of disability among construction workers. Demographic changes and a loss of interest among young people in a career in the construction industry are probably leading to an increase of the proportion of older workers in this branch of industry. This development and the considerable work related strains emphasise the importance of evaluating the health and the related risk of disability of older construction workers. It suggests also further investigations to prevent far reaching social and medical consequences.

\section{Subjects and methods}

CROSS SECTIONAL STUDY

The study population consisted of 4958 men, aged 40-64 years, who were working in Wuerttemberg in the south western part of Germany. They were examined between August 1986 and December 1988 by the Occupational Health Service of the Workmen's Compensation Board for Construction Workers Wuerttemberg as a part of routine occupational health surveillance. These occupational health examinations are based on legislation on health and safety at work (Arbeitsicherheitsgesetz). Although it is 
the duty of the employer to offer medical examinations for the employees, this is voluntary for the employees. During the period of investigation $78 \%$ of the invited employees participated in the medical examination.

The medical examination consisted of a job and medical history, a physical examination, audiometry, test of visual acuity, electrocardiography (ECG), lung function, and a blood and serum analysis. The examination was conducted by experienced occupational health physicians and documented according to a standardised protocol with fixed order and content, considering all aspects of a complete medical history and physical examination.

The study population included 388 plumbers, 521 carpenters, 633 painters/varnishers, 544 plasterers, 804 unskilled workers, 1861 bricklayers, and 207 white collar workers. The white collar workers were used as the control group. It consisted of architects, engineers, and office employees.

\section{FOLLOW UP STUDY}

Between October 1992 and June 1994, an active follow up of employment and vital status of the employees was carried out. In the follow up mortality status was found for $96.2 \%$ for the workers and disability status for $92 \cdot 3 \%$. Overall, 141 men died and 341 had to leave their work due to disability. Observations of workers who left the construction industry for other reasons were considered in the analysis concerning disability only up to that date. Completeness of follow up was considerably lower among foreign workers (for mortality $92.4 \%$, for disability $86.5 \%$ ) than among workers of German nationality $(97.4 \%$, and $94.5 \%$, respectively) due to migration.

\section{STATISTICAL METHODS}

Cross sectional study

In the cross sectional study, crude prevalence and age adjusted (Mantel-Haenszel) relative prevalence $(95 \%$ confidence interval $(95 \%$ CI)) were calculated by occupational group for the following outcomes: sum of hearing loss at 2, 3, and $4 \mathrm{kHz}$ greater than 105 decibels $(\mathrm{dB})$ in at least one ear, pathological findings at lung auscultation (which were defined as rales, rhonchi, or crackling), forced expiratory volume in one second $\left(\mathrm{FEV}_{1}\right)$ less than $80 \%$ predicted, diastolic blood pressure (DBP) higher than $95 \mathrm{~mm} \mathrm{Hg}$, abnormal findings in the electrocardiogram (ECG), body mass index (BMI) greater than $27.8 \mathrm{~kg} / \mathrm{m}^{2}$, $\gamma$-glutamyl-transpeptidase (GGT) greater than $28 \mathrm{U} / 1$ (measured at $37^{\circ} \mathrm{C}$ ), reduced mobility of the spine (fingertips to floor test, Schober sign), local pain at the spine or tenderness of the paravertebral muscles (assessed by palpation of the paravertebral muscles and percussion of the spine), abnormal findings in the limbs (limited or disturbed mobility, pain, swelling, deformation, or amputation) and skin abnormalities (eczema/inflammation, itching, or dyshidrosis).

\section{Follow up study}

For the follow up study, job specific crude rates of early retirement and mortality were calculated. With the white collar group as controls, relative risks (95\% CI), adjusted for age, nationality, and smoking history were calculated for each occupational group with Cox's proportional hazards model. ${ }^{3}$

Results

CHARACTERISTICS OF SUBJECTS AT BASELINE EXAMINATIONS (TABLE 1)

At the baseline physical examination, the mean age of the employees varied between 47.9 years (plumbers) and 51.0 years (carpenters). Overall, the employees had worked for about 30 years on average, with the mean duration of employment ranging from $26 \cdot 2$ years among unskilled workers to 32.0 years among plasterers. The proportion of foreign workers varied from $1.5 \%$ (white collar employees) to $57 \cdot 7 \%$ (unskilled workers). Most of the foreign workers came from southern Europe (Turkey, former Yugoslavia, Italy).

Smoking history was recorded for $76 \%$ of all workers, and information about alcohol consumption was obtained from $83 \%$. About half of all blue collar construction workers were current smokers and daily alcohol drinkers, whereas the respective proportions were much smaller for the white collar workers. The highest prevalence of abstainers was found among the unskilled workers, which is probably due to the higher proportion of Muslims in this group.

MORBIDITY (TABLE 2)

Table 2 shows the crude prevalence of selected findings at the baseline examination by each occupational group. Compared with the white collar workers, the construction workers showed higher crude prevalences for most of

Table 1 Characteristics of the study population: professions, age, average working period, nationality, smoking history, and alcohol consumption

\begin{tabular}{|c|c|c|c|c|c|c|c|}
\hline & Plumbers & Carpenters & $\begin{array}{l}\text { Painters/ } \\
\text { varnishers }\end{array}$ & Plasterers & $\begin{array}{l}\text { Unskilled } \\
\text { workers }\end{array}$ & Bricklayers & $\begin{array}{l}\text { White collar } \\
\text { employees }\end{array}$ \\
\hline Number & 388 & 521 & 633 & 544 & 804 & 1861 & 207 \\
\hline Age (mean (SD), y) & $47 \cdot 9(5 \cdot 4)$ & $51 \cdot 0(5 \cdot 5)$ & $49 \cdot 3(5 \cdot 2)$ & $50 \cdot 1(5 \cdot 3)$ & $50 \cdot 4(5 \cdot 7)$ & $50 \cdot 1(5 \cdot 3)$ & $49 \cdot 9(6 \cdot 1)$ \\
\hline Working period (mean $(\mathrm{SD}), \mathrm{y})$ & $29.5(6.9)$ & $31.6(8 \cdot 0)$ & $31.7(7 \cdot 5)$ & $32 \cdot 0(7 \cdot 3)$ & $26 \cdot 2(8 \cdot 6)$ & $29 \cdot 8(7 \cdot 9)$ & $28.0(7.9)$ \\
\hline Foreign workers (\%) & $5 \cdot 9$ & $25 \cdot 0$ & $13 \cdot 1$ & $16 \cdot 2$ & $57 \cdot 7$ & $32 \cdot 8$ & 1.5 \\
\hline \multicolumn{8}{|l|}{ Smoking history (\%): } \\
\hline Never & $19 \cdot 7$ & $26 \cdot 5$ & $16 \cdot 3$ & $14 \cdot 8$ & $19 \cdot 5$ & $19 \cdot 4$ & $38 \cdot 5$ \\
\hline Former & $29 \cdot 4$ & $25 \cdot 1$ & $27 \cdot 5$ & $29 \cdot 3$ & $17 \cdot 3$ & $26 \cdot 2$ & $20 \cdot 9$ \\
\hline Current & $50 \cdot 9$ & $48 \cdot 4$ & $56 \cdot 2$ & $55 \cdot 9$ & $63 \cdot 2$ & $54 \cdot 4$ & $40 \cdot 6$ \\
\hline \multicolumn{8}{|l|}{ Alcohol consumption (\%): } \\
\hline Occasional & $49 \cdot 1$ & $33 \cdot 5$ & $41 \cdot 3$ & $37 \cdot 4$ & $25 \cdot 2$ & $28 \cdot 8$ & $62 \cdot 6$ \\
\hline Daily & $47 \cdot 8$ & $58 \cdot 3$ & $56 \cdot 1$ & $58 \cdot 2$ & $59 \cdot 6$ & $62 \cdot 2$ & $27 \cdot 9$ \\
\hline
\end{tabular}


Table 2 Crude prevalence of abnormal findings by occupation (\%)

\begin{tabular}{|c|c|c|c|c|c|c|c|c|}
\hline Crude prevalence (\%) & Plumbers & Carpenters & $\begin{array}{l}\text { Painters/ } \\
\text { varnishers }\end{array}$ & Plasterers & $\begin{array}{l}\text { Unskilled } \\
\text { workers }\end{array}$ & Bricklayers & $\begin{array}{l}\text { White collar } \\
\text { employees }\end{array}$ & $\begin{array}{l}\text { All blue collar } \\
\text { workers }\end{array}$ \\
\hline \multicolumn{9}{|l|}{ Ear: } \\
\hline $\begin{array}{l}\text { Hearing loss at } 2,3 \text {, and } 4 \\
\mathrm{kHz}>105 \mathrm{~dB}\end{array}$ & $46 \cdot 3$ & $62 \cdot 6$ & $39 \cdot 8$ & $45 \cdot 3$ & $60 \cdot 7$ & $53 \cdot 4$ & 33.9 & $52 \cdot 4$ \\
\hline \multicolumn{9}{|l|}{ Lung: } \\
\hline Findings at lung auscultation & $5 \cdot 2$ & $8 \cdot 1$ & $3 \cdot 6$ & $7 \cdot 5$ & $11 \cdot 8$ & $6 \cdot 9$ & $2 \cdot 9$ & $7 \cdot 4$ \\
\hline $\mathrm{FEV}_{1}<80 \%$ predicted & $12 \cdot 7$ & $17 \cdot 7$ & $18 \cdot 3$ & $17 \cdot 2$ & $22 \cdot 5$ & $16 \cdot 7$ & $14 \cdot 3$ & 17.7 \\
\hline \multicolumn{9}{|l|}{ Circulation: } \\
\hline Diastolic blood pressure & & & & & & & & \\
\hline$>95 \mathrm{~mm} \mathrm{Hg}$ & $30 \cdot 8$ & $31 \cdot 2$ & $29 \cdot 0$ & $30 \cdot 9$ & $32 \cdot 0$ & $33 \cdot 4$ & $27 \cdot 8$ & $31 \cdot 8$ \\
\hline ECG abnormalities & $4 \cdot 9$ & $6 \cdot 0$ & $6 \cdot 2$ & $7 \cdot 5$ & $8 \cdot 1$ & 6.9 & $5 \cdot 3$ & $6 \cdot 8$ \\
\hline $\mathrm{BMI}>27.8 \mathrm{~kg} / \mathrm{m}^{2}$ & $36 \cdot 2$ & $40 \cdot 9$ & $33 \cdot 1$ & $39 \cdot 9$ & $32 \cdot 6$ & $40 \cdot 3$ & $24 \cdot 1$ & 37.7 \\
\hline Lipids: & & & & & & & & \\
\hline $\begin{array}{l}\text { Cholesterol }>220 \mathrm{mg} / \mathrm{dl} \\
\text { Liver: }\end{array}$ & $60 \cdot 8$ & $65 \cdot 6$ & $62 \cdot 7$ & $57 \cdot 4$ & $51 \cdot 7$ & $60 \cdot 6$ & $58 \cdot 5$ & $59 \cdot 6$ \\
\hline $\mathrm{GGl}>28 \mathrm{U} / 1$ & $35 \cdot 8$ & $34 \cdot 4$ & $41 \cdot 1$ & $38 \cdot 1$ & $30 \cdot 2$ & $35 \cdot 3$ & $21 \cdot 7$ & $35 \cdot 5$ \\
\hline Musculoskeletal system: & & & & & & & & \\
\hline $\begin{array}{l}\text { Reduced mobility of the spine } \\
\text { Pain at the spine or tenderness }\end{array}$ & $17 \cdot 8$ & $24 \cdot 3$ & $15 \cdot 2$ & $20 \cdot 3$ & $23 \cdot 1$ & $23 \cdot 7$ & $9 \cdot 4$ & $21 \cdot 7$ \\
\hline of paravertebral muscles & $30 \cdot 0$ & $30 \cdot 6$ & $25 \cdot 7$ & $28 \cdot 4$ & $32 \cdot 0$ & $32 \cdot 5$ & $18 \cdot 5$ & $30 \cdot 7$ \\
\hline Symptoms in the arms and legs & $32 \cdot 2$ & $42 \cdot 0$ & $28 \cdot 4$ & $32 \cdot 9$ & $31 \cdot 5$ & $34 \cdot 1$ & $24 \cdot 2$ & $33 \cdot 5$ \\
\hline Skin: & & & & & & & & \\
\hline Abnormal findings & $20 \cdot 6$ & $24 \cdot 9$ & $20 \cdot 0$ & $22 \cdot 5$ & $28 \cdot 7$ & $25 \cdot 5$ & $19 \cdot 6$ & $24 \cdot 5$ \\
\hline
\end{tabular}

the investigated items. For example, the prevalence of hearing loss varied from $33.9 \%$ (white collar workers) to over $60 \%$ (unskilled workers, carpenters). The prevalence of findings related to obstructive lung disorders was highest among the unskilled workers. Nearly a third of all investigated men showed an increased diastolic blood pressure $(>95 \mathrm{~mm}$ $\mathrm{Hg}$ ).

A higher proportion of construction workers had an increased BMI compared with white collar workers. The prevalence of increased GGT $(>28 \mathrm{U} / 1)$ was clearly higher among all groups of construction workers $(30 \cdot 2 \%$ $42.2 \%)$ than among the white collar workers $(21 \cdot 7 \%)$. All construction workers had a higher prevalence of musculoskeletal abnormalities than white collar workers and also a higher prevalence of skin disorders (eczema/inflammation, itching, dyshidrosis).

AGE ADJUSTED PREVALENCE RATIOS (TABL.E 3) After adjusting for age all groups of construc- tion workers had a significantly higher prevalence $(\alpha=0.05)$ of increased GGT, increased $\mathrm{BMI}$, and reduced mobility of the spine than the white collar workers. A significantly higher prevalence of musculoskeletal abnormalities (local pain at the spine or tenderness of paravertebral muscles, findings in the arms and legs) were found in most groups of blue collar workers. Furthermore, the age adjusted relative prevalence of hearing loss and a pathological finding at lung auscultation were higher for construction workers than white collar workers. Significantly increased prevalences of reduced $\mathrm{FEV}_{1}(<80 \%$ predicted) and of dermal abnormalities were only found in the group of the unskilled workers.

RESULTS OF THE FOLLOW LP (TABLE 4)

During the follow up period, 340 men retired due to disability and 141 men died. The most important causes of disability were diseases of the musculoskeletal system $(40 \%)$ and diseases of the cardiovascular system $(24 \%)$.

Table 3 Age adjusted prevalence ratios (95\% CI): white collar workers are controls

\begin{tabular}{|c|c|c|c|c|c|c|c|c|}
\hline & Plumbers & Carpenters & $\begin{array}{l}\text { Painters/ } \\
\text { varnishers }\end{array}$ & Plasterers & $\begin{array}{l}\text { Unskilled } \\
\text { workers }\end{array}$ & Bricklayers & $\begin{array}{l}\text { White collar } \\
\text { employees }\end{array}$ & $\begin{array}{l}\text { All blue collar } \\
\text { workers }\end{array}$ \\
\hline \multicolumn{9}{|l|}{ Ear: } \\
\hline $\begin{array}{l}\text { Hearing loss at } 2,3, \text { and } 4 \\
\mathrm{kHz}>105 \mathrm{~dB}\end{array}$ & 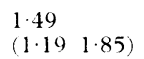 & 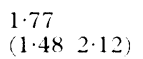 & $\begin{array}{ll}1 \cdot 20 & \\
(0.96 & 1.49)\end{array}$ & $\begin{array}{l}1 \cdot 29 \\
(1 \cdot 05 \cdot 1 \cdot 59)\end{array}$ & $\begin{array}{l}1 \cdot 75 \\
(1 \cdot 47-2 \cdot 09)\end{array}$ & $\begin{array}{l}1.55 \\
(1.301 .86)\end{array}$ & 1 & $\begin{array}{l}1.53 \\
(1.29 \quad 1.82)\end{array}$ \\
\hline \multicolumn{9}{|l|}{ Lung: } \\
\hline Findings at lung auscultation & $\begin{array}{l}1.80 \\
(0.72 \quad 4.50)\end{array}$ & $\begin{array}{l}2 \cdot 75 \\
(1 \cdot 24 \quad 6 \cdot 10)\end{array}$ & $\begin{array}{l}1 \cdot 36 \\
(0 \cdot 56 \cdot 3 \cdot 34)\end{array}$ & $\begin{array}{l}2.55 \\
(1.125 .81)\end{array}$ & $\begin{array}{l}3.97 \\
(1.928 \cdot 19)\end{array}$ & $\begin{array}{l}2 \cdot 41 \\
(1 \cdot 11 \quad 5 \cdot 21)\end{array}$ & 1 & $\begin{array}{l}2 \cdot 55 \\
(1 \cdot 20 \cdot 5 \cdot 39)\end{array}$ \\
\hline $\mathrm{FEV}<80 \%$ predicted & $\begin{array}{l}0.95 \\
(0.56 \\
1.59)\end{array}$ & $\begin{array}{l}1.13 \\
(0.74 \quad 1.74)\end{array}$ & $\begin{array}{l}1 \cdot 34 \\
(0 \cdot 88-2 \cdot 04)\end{array}$ & 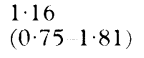 & 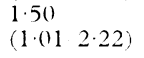 & $\begin{array}{l}1 \cdot 14 \\
(0 \cdot 77-1 \cdot 70)\end{array}$ & 1 & $\begin{array}{l}1 \cdot 23 \\
(() \cdot 84 \quad 1 \cdot 40)\end{array}$ \\
\hline \multicolumn{9}{|l|}{ Circulation: } \\
\hline $\begin{array}{l}\text { Diastolic blood pressure } \\
>95 \mathrm{~mm} \mathrm{Hg}\end{array}$ & $\begin{array}{ll}1.18 & \\
(0.90 & 1.54)\end{array}$ & $\begin{array}{l}1.05 \\
(0 \cdot 82-1 \cdot 34)\end{array}$ & $\begin{array}{l}1 \cdot 05 \\
(0 \cdot 82-1 \cdot 35)\end{array}$ & $\begin{array}{l}1.08 \\
(0.84 \quad 1.39)\end{array}$ & $\begin{array}{l}1 \cdot 12 \\
(0 \cdot 88-1 \cdot 42)\end{array}$ & $\begin{array}{l}1 \cdot 19 \\
(0.95-1.48)\end{array}$ & 1 & $\begin{array}{l}1.13 \\
(0.91-1.41)\end{array}$ \\
\hline ECG abnormalities & $\begin{array}{l}1 \cdot 01 \\
(0 \cdot 39-2 \cdot 61)\end{array}$ & $\begin{array}{l}1 \cdot 01 \\
(0 \cdot 47 \cdot 2 \cdot 17)\end{array}$ & $\begin{array}{l}1.13 \\
(0.52-2.46)\end{array}$ & $\begin{array}{l}1.32 \\
(0.62-2.79)\end{array}$ & $\begin{array}{l}1.39 \\
(0.68 \\
\end{array}$ & $\begin{array}{l}1.23 \\
(0 \cdot 62-2 \cdot 47)\end{array}$ & 1 & $\begin{array}{ll}1 \cdot 22 \\
(0.62 & 2.71)\end{array}$ \\
\hline $\mathrm{BMI}>27.8 \mathrm{~kg} / \mathrm{m}^{-}$ & $\begin{array}{l}1 \cdot 56 \\
(1 \cdot 19-2 \cdot 03)\end{array}$ & $\begin{array}{l}1 \cdot 65 \\
(1 \cdot 292 \cdot 12)\end{array}$ & $\begin{array}{l}1 \cdot 37 \\
(1 \cdot 05-1 \cdot 77)\end{array}$ & $\begin{array}{l}1 \cdot 64 \\
(1 \cdot 28-2 \cdot 10)\end{array}$ & $\begin{array}{l}1 \cdot 34 \\
(1 \cdot 04-1 \cdot 73)\end{array}$ & $\begin{array}{l}1 \cdot 65 \\
(1 \cdot 31-2 \cdot 06)\end{array}$ & 1 & $\begin{array}{l}1.56 \\
(1 \cdot 25-1 \cdot 94)\end{array}$ \\
\hline \multicolumn{9}{|l|}{ Lipids: } \\
\hline Cholesterol > $220 \mathrm{mg} \mathrm{dl}$ & $\begin{array}{ll}1.07 \\
(0.93 & 1.23)\end{array}$ & $\begin{array}{ll}1 \cdot 12 & \\
(0 \cdot 99 & 1 \cdot 27)\end{array}$ & $\begin{array}{l}1.07 \\
(0 \cdot 94-1 \cdot 22)\end{array}$ & $\begin{array}{l}0 \cdot 97 \\
(0 \cdot 84-1 \cdot 11)\end{array}$ & $\begin{array}{l}0.88 \\
(0.76-1.01)\end{array}$ & $\begin{array}{l}1 \cdot 03 \\
(0 \cdot 92-1 \cdot 16)\end{array}$ & 1 & $\begin{array}{l}1 \cdot 02 \\
(0 \cdot 91 \cdots 1 \cdot 14)\end{array}$ \\
\hline GGI > $28 \mathrm{U} / 1$ & $\begin{array}{l}1 \cdot 66 \\
(1 \cdot 25 \quad 2 \cdot 20)\end{array}$ & $\begin{array}{l}1.54 \\
(1 \cdot 18 \quad 2 \cdot 01)\end{array}$ & $\begin{array}{l}1 \cdot 87 \\
(1 \cdot 46 \cdot 2 \cdot 40)\end{array}$ & $\begin{array}{ll}1 \cdot 71 & \\
(1 \cdot 33 & 2 \cdot 22)\end{array}$ & $\begin{array}{l}1.39 \\
(1 \cdot(16-1 \cdot 81)\end{array}$ & $\begin{array}{l}1.59 \\
(1.25-2.03)\end{array}$ & 1 & $\begin{array}{l}1 \cdot 62 \\
(1 \cdot 28-2 \cdot 09)\end{array}$ \\
\hline \multicolumn{9}{|l|}{ Musculoskeletal system: } \\
\hline Reduced mobility of the spine & $\begin{array}{ll}2 \cdot 12 \\
(1.34 & 3 \cdot 34)\end{array}$ & $\begin{array}{l}2.37 \\
(1.56-3.60)\end{array}$ & $\begin{array}{l}1.67 \\
(1.07-2.61)\end{array}$ & $\begin{array}{l}2 \cdot 11 \\
(1 \cdot 38 \cdot 3 \cdot 22)\end{array}$ & $\begin{array}{l}2.35 \\
(1.57 \quad 3.53)\end{array}$ & $\begin{array}{ll}\frac{2.46}{(1.67} & 3.63)\end{array}$ & 1 & $\begin{array}{l}2 \cdot 27 \\
(1.54-3 \cdot 33)\end{array}$ \\
\hline $\begin{array}{l}\text { Pain at the spine or tenderness } \\
\text { of paravertebral muscles }\end{array}$ & $\begin{array}{ll}1 \cdot 78 \\
(1.23 & 2.56)\end{array}$ & $\begin{array}{ll}1 \cdot 61 \\
(1 \cdot 13 & 2 \cdot 29)\end{array}$ & $\begin{array}{l}1.42 \\
(0.98-2 \cdot 06)\end{array}$ & $\begin{array}{l}1 \cdot 53 \\
(1 \cdot 07 \cdot 2 \cdot 19)\end{array}$ & $\begin{array}{ll}1 \cdot 72 & \\
(1 \cdot 23 & 2 \cdot 40)\end{array}$ & $\begin{array}{l}1 \cdot 76 \\
(1 \cdot 29 \cdot 2 \cdot 42)\end{array}$ & 1 & $\begin{array}{l}1 \cdot 67 \\
(1 \cdot 22 \cdot 2 \cdot 24)\end{array}$ \\
\hline Symptoms in the arms and legs & $\begin{array}{l}1 \cdot 41 \\
(1 \cdot 07-1 \cdot 85)\end{array}$ & $\begin{array}{l}1 \cdot 67 \\
(1 \cdot 31 \cdot 2 \cdot 13)\end{array}$ & $\begin{array}{l}1.20 \\
(0.92 \quad 1.57)\end{array}$ & $\begin{array}{l}1 \cdot 35 \\
(1 \cdot 04-1 \cdot 75)\end{array}$ & $\begin{array}{l}1 \cdot 26 \\
(0 \cdot 98-1 \cdot 63)\end{array}$ & $\begin{array}{l}1 \cdot 41 \\
(1 \cdot 11-1 \cdot 78)\end{array}$ & 1 & $\begin{array}{l}1 \cdot 38 \\
(1 \cdot 09-1 \cdot 73)\end{array}$ \\
\hline $\begin{array}{l}\text { Skin: } \\
\text { Abnormal findings }\end{array}$ & $\begin{array}{ll}1 \cdot 06 & \\
(0.75 & 1.49)\end{array}$ & $\begin{array}{ll}1.28 & \\
(0.94 & 1.75)\end{array}$ & $\begin{array}{l}1 \cdot 02 \\
(0 \cdot 74-1 \cdot 41)\end{array}$ & $\begin{array}{l}1 \cdot 13 \\
(0 \cdot 82-1.55)\end{array}$ & $\begin{array}{l}1 \cdot 47 \\
(1 \cdot 10-1 \cdot 96)\end{array}$ & $\begin{array}{l}1 \cdot 30 \\
(0 \cdot 98-1.72)\end{array}$ & 1 & $\begin{array}{l}1 \cdot 25 \\
(0 \cdot 95-1 \cdot 64)\end{array}$ \\
\hline
\end{tabular}


Table 4 fob specific results of the follow up (crude disability and mortality rates;relative rates ${ }^{*}$ )

\begin{tabular}{|c|c|c|c|c|c|c|c|c|}
\hline & Plumbers & Carpenters & $\begin{array}{l}\text { Painters/ } \\
\text { varnishers }\end{array}$ & Plasterers & $\begin{array}{l}\text { Unskilled } \\
\text { workers }\end{array}$ & Bricklayers & White collar & $\begin{array}{l}\text { All blue collar } \\
\text { workers pooled }\end{array}$ \\
\hline $\begin{array}{l}\text { Number at start of follow up } \\
\text { Disability: }\end{array}$ & 388 & 521 & 633 & 544 & 804 & 1861 & 207 & 4751 \\
\hline Person-years & 1756 & 2108 & 2794 & 2258 & 2898 & 7441 & 946 & 19254 \\
\hline Events (n) & 16 & 38 & 33 & 46 & 68 & 136 & 3 & 337 \\
\hline Crude rate $(/ 100000$ p-y $)$ & 911 & 1803 & 1181 & 2037 & 2347 & 1828 & 317 & 1750 \\
\hline $\begin{array}{l}\text { Adjusted }{ }^{\star} \text { relative rate } \\
(95 \% \mathrm{CI})\end{array}$ & $\begin{array}{c}3 \cdot 52 \\
(1 \cdot 03-12 \cdot 12)\end{array}$ & $\begin{array}{c}4 \cdot 84 \\
(1 \cdot 49-15 \cdot 72)\end{array}$ & $\begin{array}{c}3 \cdot 68 \\
(1 \cdot 13-12 \cdot 04)\end{array}$ & $\begin{array}{c}5 \cdot 97 \\
(1 \cdot 85-19 \cdot 23)\end{array}$ & $\begin{array}{c}8 \cdot 39 \\
(2 \cdot 62-26 \cdot 90)\end{array}$ & $\begin{array}{c}5 \cdot 89 \\
(1 \cdot 87-18 \cdot 54)\end{array}$ & $\begin{array}{c}1 \\
\text { (control) }\end{array}$ & $\begin{array}{c}5 \cdot 39 \\
(1 \cdot 73-16 \cdot 85)\end{array}$ \\
\hline \multicolumn{9}{|l|}{ Mortality: } \\
\hline Deaths (n) & & 12 & 13 & 20 & 28 & 55 & 4 & 137 \\
\hline Crude rate $(/ 100000 \mathrm{p}$-y) & 483 & 518 & 437 & 805 & 826 & 677 & 412 & 648 \\
\hline Adjusted ${ }^{\star}$ relative rate & 1.55 & $1 \cdot 29$ & $1 \cdot 21$ & 2.05 & $2 \cdot 51$ & 1.96 & 1 & $1 \cdot 78$ \\
\hline$(95 \% \mathrm{CI})$ & $(0 \cdot 47-5 \cdot 09)$ & $(0 \cdot 41-4.03)$ & $(0 \cdot 39-3 \cdot 74)$ & $(0 \cdot 69-6 \cdot 07)$ & $(0 \cdot 86-7 \cdot 33)$ & $(0 \cdot 70-5 \cdot 49)$ & (control) & $(0 \cdot 65-4 \cdot 87)$ \\
\hline
\end{tabular}

*Adjusted for age, nationality, and smoking history.

Unskilled workers, plasterers, bricklayers, and carpenters had the highest disability rates, followed by painters/varnishers, plumbers, and the white collar group. Compared with the white collar group, each group of construction workers had a significantly higher rate of disability after controlling for age, nationality, and smoking history. The unskilled workers, plasterers, and the bricklayers showed a six to eightfold higher rate of disability than the white collar workers.

Mortalities for the construction workers were also higher than rates for white collar workers, but the increase was smaller than for disability and was not significant. Unskilled workers, plasterers, and bricklayers had the highest mortalities.

\section{Discussion}

Among the limitations of this study is the fact that it is based on examinations that were routinely performed by many different physicians. Use of a fully standardised protocol, however, should have ensured a reasonable degree of comparability. Furthermore, although the size of the control group was comparatively small, it reflects the proportion of white collar workers to blue collar workers in the construction industry, especially in small companies. Other limitations include selection mechanisms, like the healthy worker effect or selective survival, but these would typically result in an underestimate of the associations. Therefore, despite these limitations, the results show a variety of restrictions concerning the health of older construction workers compared with the white collar control group. It is possible that as well as being affected by work the higher morbidity among the construction workers may be affected by other aspects, such as social conditions and attitudes.

For a long time hearing deficiencies caused by noise have been one of the most important occupational diseases in Germany, and the high number of elderly people with noise induced losses present a formidable challenge. ${ }^{4}$ The National Institute for Occupational Safety and Health estimates that a quarter of workers of 55 years of age or older in the United States exposed to noise levels above $90 \mathrm{~dB}(\mathrm{~A})$ have a substantial hearing impairment. ${ }^{56}$ Hearing deficiencies may occur even after brief exposure to high decibel noises. Small but irreversible damage occurs during the earliest stages of beginning hearing loss without the person being cognisant that a physical injury has taken place. ${ }^{6}$ Due to the frequent use of noisy machinery, such as mechanical saws, compressors, grinding machines, drills, and other cutting tools, the construction workers' exposure to noise is remarkably high. In our study, carpenters, unskilled workers, bricklayers, plumbers, and plasterers had the highest prevalence of hearing loss. This result is consistent with the findings of two other large studies among construction workers in Germany. $^{78}$ Furthermore, in a study of iron construction workers premature deafness and balance dysfunction were described to be due to the noisy work environment, mainly caused by air impact power tools. ${ }^{9}$ It seems plausible that the higher prevalence of hearing loss found in these occupational groups is related to the work related noise exposure.

Unskilled workers, carpenters, and bricklayers had the highest prevalence of abnormal findings of the lung, which may indicate an obstructive lung disease (such as bronchitis, obstructive emphysema, or asthma). Similar results were found in other German studies. ${ }^{78}$ Smoking, air pollution, recurrent infections of the airways, climatic conditions, predisposition, and socioeconomic factors are mainly responsible for developing such diseases. ${ }^{10}$ Also, exposure to inert dust and organic solvents were described as risk factors for obstructive lung diseases. ${ }^{11}$ Dust inhalation is very common in construction workers, leading to irritation of the mucosa resulting in a hypersecretion of mucus and obstruction of the airway. ${ }^{12}$ The high prevalence of smoking among the construction workers in this study may also contribute to the increased prevalence of lung disease.

There were no significant differences in the prevalence of abnormalities on ECG or increased diastolic blood pressure between construction workers and white collar workers. A large variety of risk factors for hypertension have been discussed-namely, genetic predisposition, obesity, nutritional factors, and psychosociological factors. ${ }^{13}$ Worksite and job characteristics have also been described as important predictors of blood pressure. ${ }^{1415}$ Several metals have been associated with disturbances in cardiovascular function, but their causative role has not been fully established. ${ }^{16}$ Also, exposure to vibration might be a risk fac- 
tor for hypertension. ${ }^{17}$

The role of obesity and hypercholesterolaemia as risk factors for coronary heart disease, diabetes, and gout is well known, and a relation between obesity and musculoskeletal disorders has also been described. ${ }^{18} 19$ In our study, all groups of construction professionals showed a higher prevalence of increased BMI than white collar workers, but no differences were found for prevalence of an increased cholesterol concentration. In general BMI is a measure of obesity, but a high BMI may also partly result from high muscle mass among construction workers.

The prevalence of increased GGT was higher in all investigated professions of the construction industry than in the white collar group. Increased concentrations of GGT may be due to various causes, ${ }^{2021}$ but a very likely explanation for the increased concentrations in construction workers is their high alcohol consumption. ${ }^{22}$ Nevertheless, there is a potential for liver disorders related to work due to the exposure to paints, varnishes, organic solvents, and adhesives in the construction industry. ${ }^{2324}$

Disorders of the musculoskeletal system, especially back problems, are common in the general population as well as occupational cohorts. They are the most important cause of early retirement (invalidity) in Germany. ${ }^{2}$ Many occupational studies have investigated the influence of occupational factors on musculoskeletal complaints. ${ }^{25}$ Heavy lifting is consistently described as a risk factor of back pain in occupational studies, ${ }^{29}$ but whole body vibration, bending, kneeling, smoking, and psychosocial stress have also been identified as risk factors. ${ }^{27}{ }^{31-34}$ Increased stress on the musculoskeletal system among construction workers, especially carpenters and bricklayers, is described in many studies of occupational medicine. ${ }^{25} 31323536$ In our study the prevalence of musculoskeletal abnormalities of all types was higher for each group of construction workers than for white collar workers, indicating the strain on the musculoskeletal system.

Occupational diseases of the skin are common in Germany ${ }^{1}$ and other countries. Among these, chronic irritant contact dermatitis is the most common occupational skin disease. This disorder often develops after weeks or even years of exposure to a mild irritant, ${ }^{37}$ such as wet cement, plaster, wood preservatives, solvents, oils, detergents, paints, fibreglass, glues, tar, acids, and alkalis. ${ }^{38} 39$ Allergic contact dermatitis accounts for about $20 \%$ of cases of occupational contact dermatitis. ${ }^{37}$ There are many causes of this condition, but the most important for the construction industry might be exposure to chromate, cobalt, nickel, and epoxy resins. ${ }^{39} 40$ These combined effects may explain the higher prevalence of dermal findings among construction workers.

The results of our cohort study show an increased risk of disability and all cause mortality in construction workers (although the differences between professional groups are much less pronounced and not significant for all cause mortality), with highest risk for unskilled workers, plasterers, bricklayers, and carpenters. Retirement due to disability is an issue of great social importance in Germany. As mentioned earlier, about $44 \%$ of all cases of retirement are due to disability, whereas in the construction industry this proportion is about $63 \% .^{1}$ It has been asked whether the higher mortality and morbidity of workers in physically demanding jobs should be explained by occupational or social factors. ${ }^{41}$ The effects of both types of factors could not be distinguished in this study. It has been shown, however, that especially unskilled workers in the construction industry face a wide range of hazardous exposures in the workplace and show widespread adverse health effects. ${ }^{42}$ Other studies or registries showed no significant differences in all cause mortality between construction workers and the average of all workers, ${ }^{43}$ but lung diseases, malignoma, accidents, and psychiatric disorders were found to be more frequent as causes of death among construction workers than in the general population. In a mortality study conducted in the United Kingdom, an excess mortality was found for all cancers, including cancer of the lung and stomach, and for accidental death. ${ }^{44}$

In summary, this study describes considerable health impairments among older construction workers. These impairments most likely reflect both work related conditions and personal lifestyle factors and show the need for further health promotion. To reduce the overall morbidity, the main efforts should be focused to prevent disorders of the musculoskeletal system, lungs, ears, liver, and skin. Health promotion should include lowering personal and work related risk factors and improvements in occupational safety and industrial hygiene. Examples may be the reduction of heavy lifting by technical support or the substitution of the water soluble hexavalent chromate in cement by addition of ferrous sulphate. ${ }^{45}$ Working conditions should take the reduced work capacity of elderly workers into account. Workers with high risk of disability should be identified in time, and specific rehabilitation programmes should be offered to prevent further deterioration. Further research should be conducted to identify more specific predictors of disability.

This study was supported by the Association of the Workmen's Compensation Board for Construction Workers, Germany.

1 Drexel G, Francks P, Plinske W, Butz M. BK-Dok 90. Dokumentation des Berufskrankheiten-Geschehens in der Bundesrepublik Deutschland, Sankt Augustin: Hauptverband der gewerblichen Berufsgenossenschaften. 1992.

2 VDR Statistik Rentenzugang, Band 99, Frankfurt: Verband der Rentenversicherer. 1992.

3 Cox DR. Regression models and life tables. Fournal of the Royal Statistical Society B 1972;34:187-220.

4 Alberti HW. Noise and the ear. In: Ballantne J, Groves J, eds. Scott-Brown's diseases of the ear, nose and throat. Boston: Butterworth, 1979.

5 National Institute for Occupational Safety and Health. Leading work-related diseases and injuries-United Leading work-related diseases
States. $f A M A$ 1986;255:2133-4.

6 Gasaway DC. Noise-induced hearing loss. In: McCunnay RJ, ed. $A$ practical approach to occupational and environ$\mathrm{RJ}$, ed. A practical approach to occupational
mental medicine. Boston: Little Brown,1994.

7 Schnieders H, Amarotico E, Bauer E, Böttger M, Stark K, Urban K-D, et al. BauBg-Pilotstudie 2-Ergebnis
Urbatis einer arbeitsmedizinischen Untersuchung von 24892 Beschaeftigten in der Bauwirtschaft, Frankfurt: Arbeitsgemeinschaft der Bauberufsgenossenschaften. 1984 
8 Busch R, Elliehausen HJ, Frank K, Graeber A, Hegyi E, Lange H-J, et al. Fruehwarnsystem fuer die arbeitsmedizinische Betreuung insbesondere von Klein-und Mittelbetrieben, Frankfurt: Arbeitsgemeinschaft der Bauberufsgenossenschaften. 1992 .

9 Kilburn KH, Warshaw RH, Hanscom B. Are hearing loss and balance dysfunction linked in construction iron workers. Br f Ind Med 1992;49:138-41.

10 WHO Expert Committee. Identification and control of workrelated diseases. Geneva: WHO, 1985. (Technical report series, No 714.) 11 Chan-Yeung M, Malo JL. Occupational asthma. N Engl f

12 Becklake MR. Occupational exposures: evidence for a causal association with chronic obstructive pulmonary disease. Am Rev Respir Dis 1989:140:85-91.

13 Tomiak M, Gentlemen JF. Risk factors for the development of hypertension: a 10 year longitudinal study in ment of hypertension: a 10 year longitudinal
middle-aged men. $\mathcal{F}$ Hypertens $1991 ; 9: 217-3$.

14 Schlussel YR, Schnall PL, Zimbler M, Warren $\mathrm{K}$, Pickering TG. The effect of work environments on blood pressure: evidence from seven New York organizations. $\mathfrak{J}$ Hypertens 1990;8:679-85.

15 Fogari R, Zoppi A, Vanasia A, Marasi G, Villa G. Occupational noise and blood pressure. $\mathcal{f}$ Hypertens 1994;12:475-9.

16 Benowitz NL. Cardiovascular toxicology. In: La Dou J, ed. Occupational medicine. Norwalk: Appleton Lange, 1990.

17 Idzior-Walus B. Coronary risk factors in men occupationally exposed to vibration and noise. Eur Heart $\mathcal{f} 1987$; 8:1040-6.

18 Garrow J. Importance of obesity. BMF 1991;303:704-6.

19 Kannel WB. Some lessons in cardiovascular epidemiology from Framingham. Am $\mathcal{F}$ Cardiol 1976;37:269.

20 Axelson O. Solvents and the liver. Eur $\mathcal{f}$ Clin Invest, 1983; 13:109-11.

21 Chen JD, Wang JD, Jang JP, Chen YY. Exposure to mixtures of solvents among paint workers and biochemical alterations of liver function. $\mathrm{Br} \mathcal{F}$ Ind Med 1990;48: 696-701

22 Mandell W, Eaton WW, Anthony JC, Garrison R. Alcoholism and occupations: a review and analysis of 104 occupations. Alcohol Clin Exp Res 1992;16:734-46.

23 Dossing M, Arlien-Soborg P, Petersen LM, Ranek L. Liver damage associated with occupational exposure to organic solvents in house painters. Eur $\mathcal{F}$ Clin Invest 1983;13: 151-7.

24 Triebig G. Gesundheitsgefährdung durch organische Lösungsmittel. In: Brenner W, ed. Arbeitsmedizin aktuell. Stuttgart: Ecomed, 1986.

25 Vingard E, Alfredsson L, Goldie I, Hogstedt C. Occupation and osteoarthrosis of the hip and knee: a register-based cohort study. Int $\mathcal{f}$ Epidemiol 1991;20: 1025-31.

26 Lloyd MH, Gauld S, Soutar CA. Epidemiologic study of back pain in miners and office workers. Spine 1986;11: back pain

27 Frymoyer JW, Pope MH, Costanza MC, Rosen JC, Goggin JE, Wilder DG. Epidemiologic studies of low-back pain. Spine 1980;5:419-23.
28 Pietri F, Leclerc A, Boitel L, Chastang JF, Morcet JF, Blondet $M$. Low-back pain in commercial travellers. Scand 7 Work Environ Health 1992;18:52-8.

29 Svensson A-O, Andersson GBJ. The relationship of lowback pain, work history, work environment, and stress. A retrospective cross-sectional study of 38-to 64-year-old women. Spine 1989;14:517-22.

30 Westgaard RH, Jensen C, Hansen K. Individual and workrelated risk factors associated with symptoms of musculoskeletal complaints. Int Arch Occup Environ Health 1993;64:405-13.

31 Holmström EB, Lindell J, Moritz U. Low back and neck/shoulder pain in construction workers: occupational workload and psychosocial risk factors. Spine 1992:17: 663-71.

32 Holmström EB, Lindell J, Moritz U. Low back and neck/shoulder pain in construction workers: occupational workload and psychosocial risk factors. Part 2: relaworkload and psychosocial risk factors. Part 2: rela-
tionship to neck and shoulder pain. Spine 1992;17:

33 Ernst E. Smoking and back pain. Ann Rheum Dis 1991; 50:658.

34 Hulshof C, Zanten BV. Whole-body vibration and lowback pain. Int Arch Occup Environ Health 1987;59: 205-20.

35 Heliövaara $M$, Mäkelä $M$, Knekt $P$, Impivaara $O$, Aromaa A. Determinants of sciata and low-back pain. Spine 1991;16:608-14

36 Riihimäki $H$, Wickström G, Hänninen $K$, Luopajärvi $T$. Predictors of sciatic pain among concrete reinforcement workers and house painters-a five-year follow-up. Scand workers and house painters - a five-year

37 Nethercott JR. Occupational skin disorders. In: La Dou J, ed. Occupational medicine. Norwalk: Appleton Lange, 1990.

38 Kiec-Svierczynska M. Occupational dermatoses and allergy to metals in Polish construction workers manufacturing prefabricated building units. Contact Dermatitis 1990 23:27-32.

39 Coenraads PJ, Nater JP. Sickness and absence from work due to skin diseases in the construction industry. Review of the literature. Dermatosen 1984;32:17-21.

40 Ruehl R, Kersting K. Chromatarme Zemente und das Chromatekzem. Ergo Med 1992;3:70-4.

41 Stender M, Hense HW, Doring A, Keil U. Physical activity at work and cardiovascular disease risk: results from the MONICA Augsburg study. Int $\mathcal{f}$ Epidemiol 1993;22: 644-50.

42 Burkhart G, Schulte PA, Robinson C, Sieber WK, Vossenas $P$, Ringen $K$. Job tasks, potential exposures, and health risks of laborers employed in the construction industry. Am F Ind Med 1993;24:413-25.

$43 \mathrm{Her}$ Majesty's Stationary Office. Occupational mortality 1979-80; 1982-3. London: HMSO, 1985.

44 Dong W, Vaughan P, Sullivan K, Fletcher T. Mortality study of workers in the UK. Int $\mathcal{f}$ Epidemiol 1995;24: study of

45 Bruze M, Gruvberger B, Hradil E. Chromate sensitization and elicitation from cement with iron sulfate. Acta Derm Venereol 1990;70:160-2.

\section{Occupational and Environmental Medicine and the electronic age}

OEM has an Email address which is 100632.3615@compuserve.com. We welcome contact by Email, including letters to the editor. Some of our reviewers already send us their reports by Email, helping to speed up the peer review process.

We are moving towards electronic publishing and for some months now we have been asking authors to send us their revised papers on disk as well as a hard copy. I am delighted to report that nearly all our authors are managing to comply with this request; far more than for other specialist journals in the BMJ Publishing group. Oddly enough, the few authors who have not sent us a disk version of their revised papers have been almost exclusively from the United Kingdom. I would be interested in suggestions for why this might be. Perhaps United Kingdom based authors read our correspondence and instructions less assiduously? Watch for revised Instructions to Authors.

The Editor 